\title{
Sistem Pendukung Keputusan Menentukan Pemberian Pinjaman Modal dengan Metode Multi Attribute Utility Theory
}

\author{
Asyahri Hadi Nasyuha \\ Prodi Sistem Informasi, STMIK Triguna Dharma, Medan, Indonesia \\ Email: ayi.nasyuha@gmail.com
}

\begin{abstract}
Abstrak
Perkembangan teknologi yang sangat pesat, komputer dimanfaatkan tidak hanya sebatas pengolahan data saja tapi juga sebagai solusi pemecahan masalah dalam berbagai bidang ilmu, salah satunya adalah sistem pendukung keputusan. Sistem pendukung keputusan memiliki nilai tambah dalam membantu pengambilan keputusan yang dengan memanfaatkan data dan model untuk menyelesaikan masalah yang tidak terstruktur. Dalam hal ini sistem pendukung keputusan digunakan untuk menentukan peminjaman modal usaha dengan menggunakan metode Multi Attibute Utility Theory. Dari penelitian yang dilakukan, banyak masyarakat yang mengajukan peminjaman modal usaha sehingga pihak pemberi modal sulit dalam menentukan calon penerimaan modal usaha yang layak. Multi Attribute Utility Theory digunakan untuk mencari penjumlahan terbobot dari rating kinerja pada setiap alternatif berdasarkan nilai dari masing-masing kriteria. Perangkingan merupakan hasil dari perhitungan dengan menggunakan metode Multi Attribute Utility Theory.
\end{abstract}

Kata Kunci: Penentuan Pemberian Modal, Multi Attribute Utility Theory

\begin{abstract}
technology development is very rapid, computers are utilized not only limited to data processing but also as solutions to problem solving in various fields of science, one of which is a decision support system. Decision support systems have added value in helping decision making by utilizing data and models to solve unstructured problems. In this case the decision support system is used to determine business capital borrowing using the Multi Attibute Utility Theory method. From the research carried out, many people have proposed business capital loans so that the capital provider is difficult to determine the prospective acceptance of appropriate business capital. Multi Attribute Utility Theory is used to find weighted sums of performance ratings for each alternative based on the values of each criterion. Ranking is the result of calculations using the Multi Attribute Utility Theory method.
\end{abstract}

Keywords: Determination of Granting of Capital, Multi Attribute Utility Theory

\section{PENDAHULUAN}

Di Indonesia UMKM telah menjadi bagian penting dari sistem perekonomian di Indonesia. Sektor UMKM lebih sering memanfaatkan sumber daya alam dan padat karya seperti pertanian, perkebunan, peternakan, dan perdagangan. Untuk memulai membangun UMKM dibutuhkan sebuah modal usaha. Dalam hal ini sering terjadi kurangnya modal untuk membangun UMKM yang mengakibatkan dibutuhkan suatu peminjaman modal. Dalam hal ini digunakan teknik yang dapat menentukan pemberian peminjaman modal usaha UMKM yaitu dengan menggunakan Sistem Pendukung Keputusan. Suatu sistem yang dalam proses pengambilan keputusan melalui alternatif-alternatif yang diperoleh dari pengolahan data, informasi dan rancangan model.

Sistem Pendukung Keputusan ditandai dengan sistem interaktif berbasis komputer yang mampu mengambil keputusan dengan memanfaatkan data untuk menyelesaikan masalah yang tidak terstruktur. Sistem Pendukung Keputusan mempunyai beberapa metode, salah satunya adalah Multi Attribute Utility Theory. Metode Multi Attribute Utility Theory merupakan metode yang memiliki proses penyelesaian yang merupakan penggabungan antara metode Analytichal Hierarchy Process (AHP) dan metode Simple Additive Weighting (SAW). Konsep penyelesaian metode Multi Attribute Utility Theory mendefenisikan terlebih dahulu kriteriakriteria yang akan dijadikan tolak ukur penyelesaian masalah dan menentukan tingkat kepentingan setiap kriteria. Lalu menghitung nilai matriks perbandingan berdasarkan tabel nilai kepentingan, kemudian menghitung nilai bobot kriteria (Wj) dan nilai bobot preferensi (Vi) dan yang terakhir melakukan perangkingan. Berdasarkan deskripsi masalah di atas, dibuat sebuah penelitian .

\section{TEORITIS}

\subsection{Usaha Mikro Kecil dan Menengah}

Usaha Mikro, Kecil dan Menengah (UMKM) merupakan kelompok usaha yang perannya sangat signifikan dalam perekonomian Indonesia, dengan jumlah pelaku usaha mikro yang diperkirakan sebagian besar bergerak di sektor informal. Hal ini mengindikasikan gejala informalisasi perekonomian. Tenaga kerja yang tidak berhasil diserap oleh sektor formal akan beralih ke sektor informal.

\subsection{Pemberdayaan UMKM}

Pemberdayaan UMKM merupakan bagian integral dai pembangunan nasional untuk mewujudkan masyarakat Indonesia yang demokratis, adil dan makmur sesuai dengan amanat konstitusi UUD 1945. Pengembangan 
lingkungan usaha yang kondusif bagi UMKM dimaksudkan untuk meningkatkan daya saing UMKM dengan menciptakan peluang usaha seluas-luasnya, serta menjamin adanya mekanisme pasar yang sehat. Dalam rangka penumbuhan lingkungan usaha yang kondusif bagi UMKM, maka diperlukan serangkaian kebijakan ekonomi makro, kebijakan sektoral dan kebijakan pembangunan daerah yang saling melengkapi, selaras dan sinergi dalam rangka memberdayakan UMKM. Kebijakan pengembangan lingkungan usaha yang kondusif bagi UMKM tidak berada pada suatu instansi tertentu, dan cenderung tersebar pada berbagai instansi. Untuk itu, diperlukan kemampuan advokasi, persuasi dan koordinasi dengan instansi lain untuk menumbuhkan iklim berusaha yang kondusif bagi UMKM.

\subsection{Sistem Pendukung Keputusan}

Sistem Pendukung Keputusan (SPK) merupakan suatu sistem berbasis komputer yang interaktif, yang membantu pengambil keputusan memanfaatkan data dan model untuk menyelesaikan masalah-masalah yang tak terstruktur dan semi terstruktur. Menurut Kusrini (2007:15) Sistem Pendukung Keputusan merupakan sistem informasi interaktif yang menyediakan informasi, pemodelan dan pemanipulasi data. Sistem ini digunakan untuk pengambilan keputusan dalam situasi yang semiterstruktur dan tidak terstruktur. Pada dasarnya SPK dirancang untuk mendukung seluruh tahap pengambilan keputusan mulai dari mengidentifikasi masalah, memilih data yang relevan, menentukan pendekatan yang digunakan dalam proses pengambilan keputusan, sampai mengevaluasi pemilihan alernatif.

\subsection{Multi Attribute Utility Theory (MAUT)}

Metode Multi Attribute Utility Theory merupakan metode yang fundamental selain metode MFEP(Multi Factor Evaluation Process). Metode ini terlihat memiliki proses penyelesaian yang merupakan penggabungan metode Analythical Hierarchy Process (AHP) dan metode Simple Additive Weighting (SAW). Konsep dasar metode Multi Attribute Utility Theoryadalah mencari penjumlahan terbobot dari rating kinerja pada setiap alternatif pada semua atribut.Metode Multy Attribute Utility Theory membutuhkan proses normalisasi matriks keputusan (X) ke suatu skala yang dapat diperbandingkan dengan semua rating alternatif yang ada. Dalam metode Multi Attribute Utility Theory bobot dari setiap kriteria bukan ditentukan diawal tetapi ditentukan menggunakan rumus berdasarkan skala prioritas (tingkat kepentingan). Berikut ini adalah tabel tingkat kepentingan yang digunakan dalam metode Multi Attribute Utility Theory.

Tabel 1. Tingkat Kepentingan

\begin{tabular}{cl}
\hline Nilai Kepentingan & \multicolumn{1}{c}{ Keterangan } \\
\hline 1 & Kedua elemen sama pentingnya. \\
\hline 3 & $\begin{array}{l}\text { Elemen yang satu sedikit lebih penting daripada elemen } \\
\text { lainnya. }\end{array}$ \\
\hline 5 & Elemen yang satu lebih penting daripada elemen lainnya. \\
\hline 7 & $\begin{array}{l}\text { Satu elemen jelas lebih mutlak penting daripada elemen } \\
\text { lainnya. }\end{array}$ \\
\hline 9 & Satu elemen mutlak penting daripada elemen lainnya. \\
\hline
\end{tabular}

Dan dalam metode ini terdapat nilai Random Index. Adapun tabel nilai Random Index adalah sebagai berikut.

Tabel 2. Nilai Random Index(RI)

\begin{tabular}{cc}
\hline Jumlah n Kriteria & $\mathrm{RI}_{\mathrm{n}}$ \\
\hline 2 & 0 \\
\hline 3 & 0.58 \\
\hline 4 & 0.90 \\
\hline 5 & 1.12 \\
\hline 6 & 1.24 \\
\hline 7 & 1.32 \\
\hline 8 & 1.41 \\
\hline 9 & 1.45 \\
\hline 10 & 1.49
\end{tabular}

Rumus untuk menghitung nilai matriks perbandingan berpasangan :

Keterangan :

$$
\mathrm{w}_{\mathrm{j}}=\frac{1}{\mathrm{n}} \sum_{\mathrm{j}} \mathrm{a}_{\mathrm{ij}}
$$

$\mathrm{w}_{\mathrm{j}}=$ Nilai bobot kriteria 
$\mathrm{a}_{\mathrm{ij}}=$ Nilai matriks hasil perbandingan

Rumus untuk menghitung nilai preferensi untuk setiap alternatif (Vi) adalah sebagai berikut :

$$
V_{i}=\sum_{j=1}^{n} w_{j} x_{i j}
$$

Keterangan :

$\mathrm{V}_{\mathrm{i}}=$ Nilai bobot preferensi

$\mathrm{w}_{\mathrm{j}}=$ Nilai bobot kriteria

$\mathrm{x}_{\mathrm{ij}}=$ Nilai rating kinerja alternatif

\subsection{Pemodelan Sistem}

Pada perkembangan teknologi perangkat lunak, diperlukan adanya bahasa yang digunakan untuk memodelkan perangkat lunak yang akan dibuat dan perlu adanya standarisasi agar orang di berbagai negara dapat mengerti pemodelan perangkat lunak. Seperti yang kita ketahui bahwa menyatukan banyak kepala untuk menceritakan sebuah ide dengan tujuan untuk memahami hal yang sama tidaklah mudah. Oleh karena itu, diperlukan sebuah bahasa pemodelan perangkat lunak yang dapat dimengerti oleh banyak orang.

\section{ANALISA DAN PEMBAHASAN}

\subsection{Analisis Permasalahan}

Model yang digunakan untuk menetukan penerimaan peminjaman modal usaha UKM adalah dengan menggunakan metode Multi Attibute Utility Theory. Metode ini merupakan metodologi sistem kontrol pemecahan masalah yang cocok diimplementasikan pada sistem mulai dari sistem yang sederhana, sistem kecil, workstation berbasis akuitis data dan sebagainya. Metode Multi Attibute Utility Theory memiliki proses penyelesaian yang merupakan penggabungan metode Analythical Hierarchy Process (AHP) dan metode Simple Additive Weighting (SAW). Melihat permasalahan yang terjadi, maka diperlukan sebuah aplikasi yang cepat dan mampu mendukung kesimpulan untuk pengambilan keputusan dalam menetukan penerimaan peminjaman modal usaha UKM. Perancangan sebuah aplikasi untuk mendukung sebuah keputusan harus dibuat secara matang, agar tampilannya mudah dipahami dan hasilnya bermanfaat dan memuaskan bagi pengguna

\subsection{Algoritma Sistem}

Dalam menyelesaikan permasalahan yang terjadi pada Ulil Albab, dibutuhkan sebuah sistem yang mampu mempermudah pihak Ulil Albab dalam menetukan penerimaan peminjaman modal usaha UKM yang nantinya dapat diaplikasikan dalam sebuah sistem komputer dengan menggunakan metode Multi Attribute Utility Theory. Setiap output yang dihasilkan oleh sistem harus sesuai dengan hasil yang diharapkan.

Dalam metode Multi Attribute Utility Theory bobot dari setiap kriteria bukan ditentukan diawal tetapi ditentukan menggunakan rumus berdasarkan skala prioritas (tingkat kepentingan). Berikut ini adalah tabel tingkat kepentingan yang digunakan dalam metode Multi Attribute Utility Theory.

Tabel 3. Tingkat Kepentingan

\begin{tabular}{cl}
\hline $\begin{array}{c}\text { Nilai } \\
\text { Kepentingan }\end{array}$ & \multicolumn{1}{c}{ Keterangan } \\
\hline 1 & Kedua elemen sama pentingnya. \\
\hline 3 & $\begin{array}{l}\text { Elemen yang satu sedikit lebih penting daripada elemen } \\
\text { lainnya. }\end{array}$ \\
\hline 5 & Elemen yang satu lebih penting daripada elemen lainnya. \\
\hline 7 & $\begin{array}{l}\text { Satu elemen jelas lebih mutlak penting daripada elemen } \\
\text { lainnya. }\end{array}$ \\
\hline 9 & Satu elemen mutlak penting daripada elemen lainnya. \\
\hline
\end{tabular}

Dan dalam metode ini terdapat nilai RandomIndex. Adapun tabel nilai Random Index adalah sebagai berikut.

Tabel 4. Nilai Random Index(RI)

\begin{tabular}{ccc}
\hline No & Jumlah n Kriteria & $\mathrm{RI}_{\mathrm{n}}$ \\
\hline 1. & 2 & 0 \\
\hline 2. & 3 & 0.85 \\
\hline 3. & 4 & 0.90 \\
\hline 4. & 5 & 1.12 \\
\hline 5. & 6 & 1.24 \\
\hline 6. & 7 & 1.32 \\
\hline
\end{tabular}




\begin{tabular}{ccc}
\hline No & Jumlah n Kriteria & $\mathrm{RI}_{\mathrm{n}}$ \\
\hline 7. & 8 & 1.41 \\
\hline 8. & 9 & 1.45 \\
\hline 9. & 10 & 1.49 \\
\hline
\end{tabular}

Adapun algoritma sistem penyelesaian metode Multi Attribute Utility Theory adalah sebagai berikut :

1. Mendefenisikan terlebih dahulu kriteria-kriteria yang akan dijadikan tolak ukur penyelesaian masalah dan menentukan tingkat kepentingan dari setiap kriteria.

2. Menghitung nilai matriks perbandingan dari masing-masing kriteria berdasarkan tabel nilai kepentingan.

3. Menghitung nilai bobot kriteria $(\mathrm{Wj})$

4. menghitung nilai bobot preferensi (Vi)

5. Perangkingan.

Bentuk penerapan algoritma penyelesaian masalah dijelaskan dalam contoh kasus menentukan mutasi tugas berikut ini.

1. Mendefenisikan terlebih dahulu kriteria-kriteria yang akan dijadikan tolak ukur penyelesaian masalah dan menentukan tingkat kepentingan dari setiap kriteria.

Tabel 5. Kriteria Kelayakan Peminjaman Modal

\begin{tabular}{cc}
\hline Kode & Keterangan \\
\hline K1 & Jumlah Tanggungan \\
\hline K2 & Pendapatan Perbulan \\
\hline K3 & Rumah \\
\hline K4 & Sisa Hutang di Tempat Lain \\
\hline K5 & Lama Usaha \\
\hline K6 & Keaktifan Keagamaan \\
\hline
\end{tabular}

Dari setiap kriteria, pembuat keputusan akan menentukan nilai bobot dengan menentukan skala/prioritas kepentingan yang berkisar dari nilai 1 sampai 9. Selanjutnya penilaian antar kriteria berdasarkan tingkat kepentingan, dibuat dalam matriks berpasangan untuk menentukan bobot awalnya.

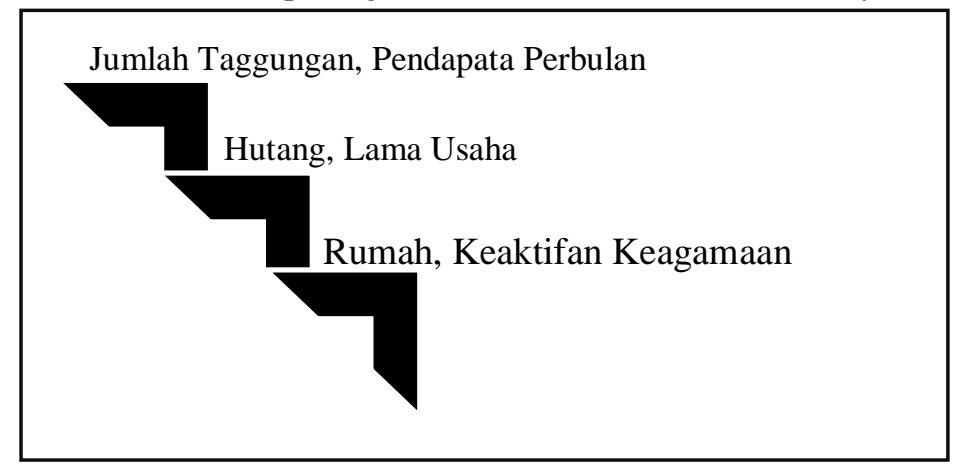

Gambar 1. Tangga Prioritas

2. Menghitung nilai matriks perbandingan dari masing-masing kriteria berdasarkan tabel nilai kepentingan.

Tabel 6. Data Penilaian Peminjaman Modal

\begin{tabular}{lcccccc}
\hline \multicolumn{1}{c}{ Nama } & K1 & K2 & K3 & K4 & K5 & K6 \\
\hline Nurhayati & 60 & 60 & 80 & 40 & 100 & 60 \\
\hline Budayati & 80 & 60 & 40 & 40 & 100 & 60 \\
\hline Suwesti Efa & 100 & 80 & 100 & 80 & 80 & 100 \\
\hline Fuad Dahri & 60 & 100 & 40 & 100 & 60 & 80 \\
\hline Riki Zunaidi & 80 & 60 & 40 & 50 & 60 & 80 \\
\hline Rubiyanti & 60 & 80 & 100 & 80 & 60 & 60 \\
\hline Vivi Juliana & 100 & 60 & 100 & 100 & 80 & 80 \\
\hline Ahmad Yani & 60 & 100 & 80 & 80 & 60 & 100 \\
\hline Rosdiana & 100 & 100 & 40 & 40 & 100 & 100 \\
\hline Affrianto & 80 & 60 & 68 & 40 & 60 & 60 \\
\hline
\end{tabular}

Tabel 7. Matriks Perbandingan Berpasangan Metode MAUT

\begin{tabular}{llllll} 
K1 & K2 & K3 & K4 & K5 & K6 \\
\hline
\end{tabular}




\begin{tabular}{ccccccc}
\hline $\mathrm{K} 1$ & 1 & 1 & $3 / 1$ & $3 / 1$ & $5 / 1$ & $5 / 1$ \\
\hline $\mathrm{K} 2$ & 1 & 1 & $3 / 1$ & $3 / 1$ & $5 / 1$ & $5 / 1$ \\
\hline $\mathrm{K} 3$ & $1 / 3$ & $1 / 3$ & 1 & 1 & $5 / 3$ & $5 / 3$ \\
\hline $\mathrm{K} 4$ & $1 / 3$ & $1 / 3$ & 1 & 1 & $5 / 3$ & $5 / 3$ \\
\hline $\mathrm{K} 5$ & $1 / 5$ & $1 / 5$ & $3 / 5$ & $3 / 5$ & 1 & 1 \\
\hline $\mathrm{K} 6$ & $1 / 5$ & $1 / 5$ & $3 / 5$ & $3 / 5$ & 1 & 1
\end{tabular}

Tabel 8. Normalisasi Matriks Perbandingan Berpasangan

\begin{tabular}{ccccccc}
\hline & K1 & K2 & K3 & K4 & K5 & K6 \\
\hline K1 & 1 & 1 & 3 & 3 & 5 & 5 \\
\hline K2 & 1 & 1 & 3 & 3 & 5 & 5 \\
\hline K3 & 0,333 & 0,333 & 1 & 1 & 1,667 & 1,667 \\
\hline K4 & 0,333 & 0,333 & 1 & 1 & 1,667 & 1,667 \\
\hline K5 & 0,2 & 0,2 & 0,6 & 0,6 & 1 & 1 \\
\hline K6 & 0,2 & 0,2 & 0,6 & 0,6 & 1 & 1 \\
\hline Jumlah & 3,067 & 3,067 & 9,2 & 9,2 & 15,333 & 15,333 \\
\hline
\end{tabular}

Menghitung nilaiw $\mathrm{w}_{\mathrm{i}}=\frac{1}{\mathrm{n}} \sum_{\mathrm{j}} \mathrm{a}_{\mathrm{ij}}$ berdasarkan tabel normalisasi matriks perbandingan berpasangan yaitu sebagai berikut.

Tabel 9. Matriks Perbandingan Berpasangan $\mathrm{w}_{\mathrm{i}}=\frac{1}{\mathrm{n}} \sum_{\mathrm{j}} \mathrm{a}_{\mathrm{ij}}$

\begin{tabular}{ccccccc}
\hline & K1 & K2 & K3 & K4 & K5 & K6 \\
\hline K1 & 0,3261 & 0,3261 & 0,3261 & 0,3261 & 0,3261 & 0,3261 \\
\hline K2 & 0,3261 & 0,3261 & 0,3261 & 0,3261 & 0,3261 & 0,3261 \\
\hline K3 & 0,1087 & 0,1087 & 0,1087 & 0,1087 & 0,1087 & 0,1087 \\
\hline K4 & 0,1087 & 0,1087 & 0,1087 & 0,1087 & 0,1087 & 0,1087 \\
\hline K5 & 0,0652 & 0,0652 & 0,0652 & 0,0652 & 0,0652 & 0,0652 \\
\hline K6 & 0,0652 & 0,0652 & 0,0652 & 0,0652 & 0,0652 & 0,0652 \\
\hline
\end{tabular}

Dari data tabel 9. diatas, dirubah dalam bentuk matriks perbandingan yaitu sebagai berikut.

$\begin{array}{llllll}0,3261 & 0,3261 & 0,3261 & 0,3261 & 0,3261 & 0,3261 \\ 0,3261 & 0,3261 & 0,3261 & 0,3261 & 0,3261 & 0,3261 \\ 0,1087 & 0,1087 & 0,1087 & 0,1087 & 0,1087 & 0,1087 \\ 0,1087 & 0,1087 & 0,1087 & 0,1087 & 0,1087 & 0,1087 \\ 0,0652 & 0,0652 & 0,0652 & 0,0652 & 0,0652 & 0,0652 \\ 0,0652 & 0,0652 & 0,0652 & 0,0652 & 0,0652 & 0,0652\end{array}$

3. Menghitung nilai bobot kriteria $(\mathrm{Wj})$

Maka berikut ini adalah nilai rata-rata dari matriks perbandingan kriteria yaitu sebagai berikut :

$\mathrm{K} 1=(0,3261+0,3261+0,3261+0,3261+0,3261+0,3261) / 6=0,3261$

$\mathrm{K} 2=(0,3261+0,3261+0,3261+0,3261+0,3261+0,3261) / 6=0,3261$

$\mathrm{K} 3=(0,1087+0,1087+0,1087+0,1087+0,1087+0,1087) / 6=0,1087$

$\mathrm{K} 4=(0,1087+0,1087+0,1087+0,1087+0,1087+0,1087) / 6=0,1087$

$\mathrm{K} 5=(0,0652+0,0652+0,0652+0,0652+0,0652+0,0652) / 6=0,0652$

$\mathrm{K} 6=(0,0652+0,0652+0,0652+0,0652+0,0652+0,0556) / 6=0,0652$

Maka nilai Bobot Kriteria $(\mathrm{Wj})=(0,3261 ; 0,3261 ; 0,1087 ; 0,1087 ; 0,0652 ; 0,0652)$

$$
\begin{aligned}
& {\left[\begin{array}{cccccc}
1 & 1 & 3 & 3 & 5 & 5 \\
1 & 1 & 3 & 3 & 5 & 5 \\
0,333 & 0,333 & 1 & 1 & 1,667 & 1,667 \\
0,333 & 0,333 & 1 & 1 & 1,667 & 1,667 \\
0,2 & 0,2 & 0,6 & 0,6 & 1 & 1 \\
0,2 & 0,2 & 0,6 & 0,6 & 1 & 1
\end{array}\right)\left(\begin{array}{l}
0,3261 \\
0,3261 \\
0,1087 \\
0,1087 \\
0,0652 \\
0,0652
\end{array}\right)=\left(\begin{array}{l}
1,9564 \\
1,9564 \\
0,6521 \\
0,6521 \\
0,3913 \\
0,3913
\end{array}\right) } \\
& t=\frac{1}{6}\left(\frac{1,9564}{0,3261}+\frac{1,9564}{0,3261}+\frac{0,6521}{0,1087}+\frac{0,6521}{0,1087}+\frac{0,3913}{0,0652}+\frac{0,3913}{0,0652}\right)=6
\end{aligned}
$$

Untuk mencari nilai CI digunakan rumus $\mathrm{CI}=\frac{\mathrm{t}-\mathrm{n}}{\mathrm{n}-1}$ 


$$
\mathrm{CI}=\frac{6-6}{5}=0
$$

Untuk $\mathrm{n}=6$ diperoleh $\mathrm{RI}_{6}=1,24$ sehingga, $\frac{\mathrm{CI}}{\mathrm{RI}}=\frac{0}{1,24}=0 \leq 1$, berarti nilainya Konsisten. 4. menghitung nilai bobot preferensi (Vi)

Tabel 10. Nilai Bobot Preferensi (Vi)

\begin{tabular}{lcccccc}
\hline \multicolumn{1}{c}{ Nama } & K1 & K2 & K3 & K4 & K5 & K6 \\
\hline Nurhayati & 60 & 60 & 80 & 40 & 100 & 60 \\
\hline Budayati & 80 & 60 & 40 & 40 & 100 & 60 \\
\hline Suwesti Efa & 100 & 80 & 100 & 80 & 80 & 100 \\
\hline Fuad Dahri & 60 & 100 & 40 & 100 & 60 & 80 \\
\hline Riki Zunaidi & 80 & 60 & 40 & 50 & 60 & 80 \\
\hline Rubiyanti & 60 & 80 & 100 & 80 & 60 & 60 \\
\hline Vivi Juliana & 100 & 60 & 100 & 100 & 80 & 80 \\
\hline Ahmad Yani & 60 & 100 & 80 & 80 & 60 & 100 \\
\hline Rosdiana & 100 & 100 & 40 & 40 & 100 & 100 \\
\hline Afrianto & 80 & 60 & 68 & 40 & 60 & 60 \\
\hline
\end{tabular}

$\mathrm{V} 1=(0,3261 * 60)+(0,3261 * 60)+(0,1087 * 80)+(0,1087 * 40)+(0,0652 * 100)+(0,0652 * 60)=62,608$

$\mathrm{V} 2=(0,3261 * 80)+(0,3261 * 60)+(0,1087 * 40)+(0,1087 * 40)+(0,0652 * 100)+(0,0652 * 60)=64,782$

$\mathrm{V} 3=(0,3261 * 100)+(0,3261 * 80)+(0,1087 * 100)+(0,1087 * 80)+(0,0652 * 80)+(0,0652 * 100)=90$

$\mathrm{V} 4=(0,3261 * 60)+(0,3261 * 100)+(0,1087 * 40)+(0,1087 * 100)+(0,0652 * 60)+(0,0652 * 80)=76,522$

V5 $=(0,3261 * 80)+(0,3261 * 60)+(0,1087 * 40)+(0,1087 * 40)+(0,0652 * 60)+(0,0652 * 80)=63,487$

V6 $=(0,3261 * 60)+(0,3261 * 80)+(0,1087 * 100)+(0,1087 * 80)+(0,0652 * 60)+(0,0652 * 60)=73,044$

V7 $=(0,3261 * 100)+(0,3261 * 60)+(0,1087 * 100)+(0,1087 * 100)+(0,0652 * 80)+(0,0652 * 100)=84,348$

$\mathrm{V} 8=(0,3261 * 60)+(0,3261 * 100)+(0,1087 * 80)+(0,1087 * 80)+(0,0652 * 60)+(0,0652 * 100)=80$

$\mathrm{V} 9=(0,3261 * 100)+(0,3261 * 100)+(0,1087 * 40)+(0,1087 * 40)+(0,0652 * 100)+(0,0652 * 100)=86,956$

$\mathrm{V} 10=(0,3261 * 80)+(0,3261 * 60)+(0,998 * 80)+(0,1087 * 40)+(0,0652 * 60)+(0,0652 * 60)=66,522$

\section{Perangkingan}

Perangkingan dilakukan untuk menentukan layak atau tidaknya pemberian pinjaman modal usaha dengan minimal total nilai adalah 70 .

Tabel 11. Perangkingan

\begin{tabular}{lcl}
\hline Nama Personel & Total Nilai & \multicolumn{1}{c}{ Keterangan } \\
\hline Nurhayati & 62,608 & Tidak Layak \\
\hline Budayati & 64,782 & Tidak Layak \\
\hline Suweti Efa & 90 & Layak \\
\hline Fuad Dahri & 76,522 & Layak \\
\hline Riki Zunaidi & 63,487 & Tidak Layak \\
\hline Rubiyanti & 73,044 & Layak \\
\hline Vivi Juliana & 84,348 & Layak \\
\hline Ahmad Yani & 80 & Layak \\
\hline Rosdiana & 86,965 & Layak \\
\hline Afrianto & 66,522 & Tidak Layak \\
\hline
\end{tabular}

\section{IMPLEMENTASI}

Implementasi sistem merupakan bagian yang menerangkan tentang penerapan dan hasil dari sistem pendukung keputusan yang dijelaskan secara satu persatu. Dimulai dari form login kemudian diteruskan ke menu utama, menu data, menu proses dan terakhir menu laporan.

\subsection{Form Login}

Form Login adalah tampilan yang pertama kali tampil ketika program dijalankan, form login digunakan oleh user untuk masuk ke dalam sistem lalu ke form menu utama. Di bawah ini merupakan tampilan form login sebagai berikut: 


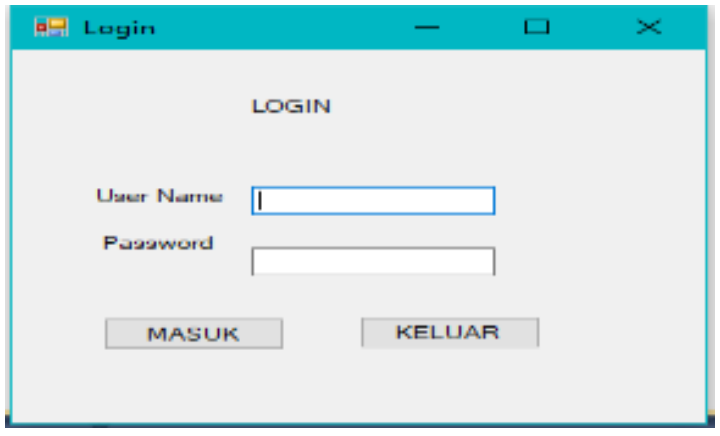

Gambar 2. Tampilan Form Login

\subsection{Form Data Anggota}

Form Data Anggota adalah tampilan yang berisi data-data. Form ini juga berfungsi sebagai media penambahan data anggota yang akan diberikan pinjaman, menghapus dan mengubah. Di bawah ini merupakan tampilan form data anggota sebagai berikut:

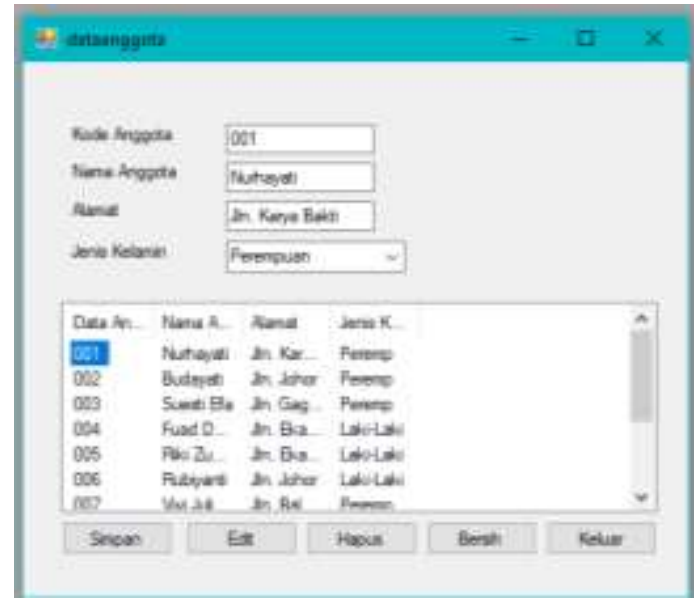

Gambar 3. Tampilan form data anggota

\subsection{Form Data Kriteria}

Form Data Kriteria berisi tentang tampilan data kriteria yang digunakan dalam menentukan kriterai-kriteria pengambilan keputusan pemindahan tugas pegawai, tetapi tidak bisa melakukan penambahan/penghapusan kriteria. Sebab kriteria sudah ditetapkan 5 kriteria oleh perusahaan. Di bawah ini merupakan tampilan form data kriteria sebagai berikut:

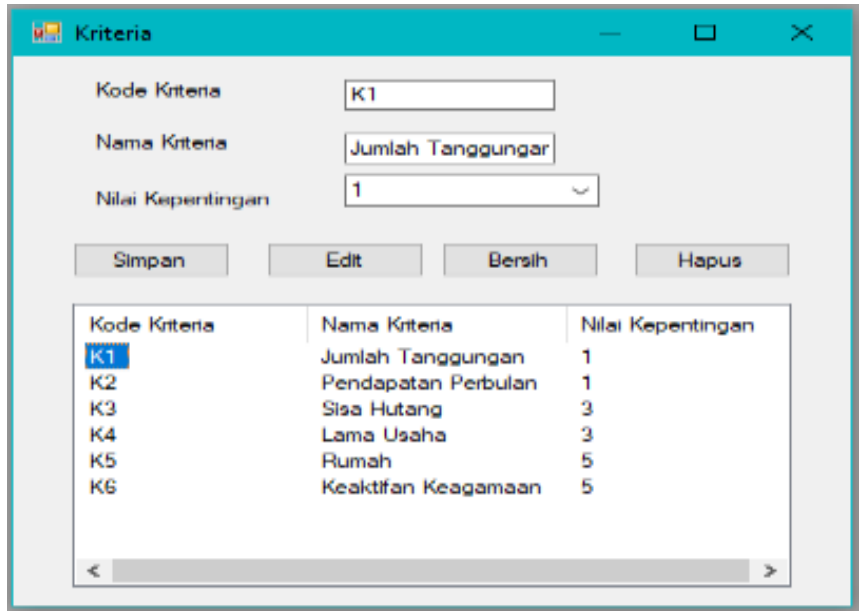

\subsection{Form Penilaian}

Gambar 4. Tampilan form data kriteria

Form ini berfungsi untuk mengisi nilai-nilai kriteria tiap data alternatif kemudian melakukan proses perhitungan nilai kriteria tersebut dan menampilkan hasil penilaian yang menentukan seorang pegawai tersebut dinyatakan 
pindah tugas atau tidak. Dalam kasus ini hasil penilaian dinyatakan pindah tugas nilai minimal 5 yang telah ditentukan perusahaan. Di bawah ini merupakan tampilan form penilaian sebagai berikut:

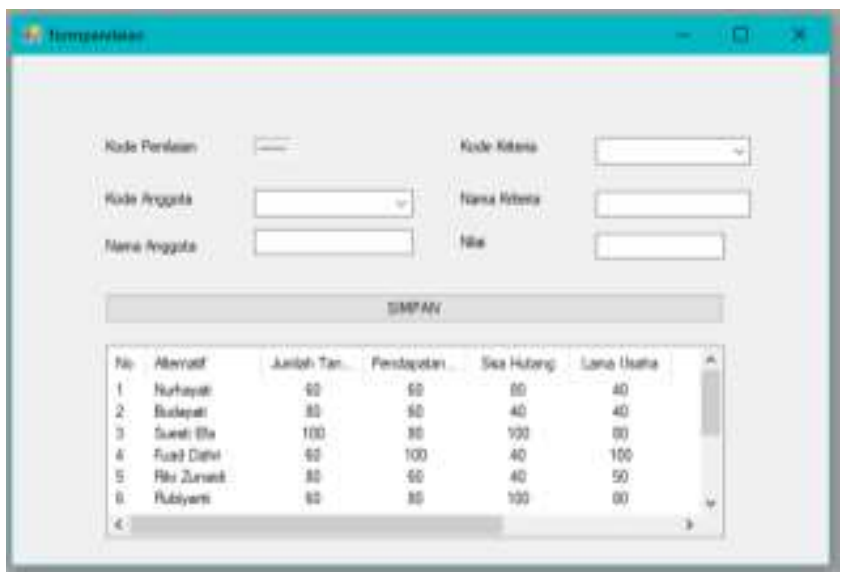

Gambar 5. Tampilan form penilaian

\subsection{Form Maut}

Form maut merupakan form yang berisikan fungsi tentang perhitungan metode dengan mengamsumsi nilai-nilai kriteria yang telah diketahui. Di bawah ini merupakan tampilan form penilaian sebagai berikut:

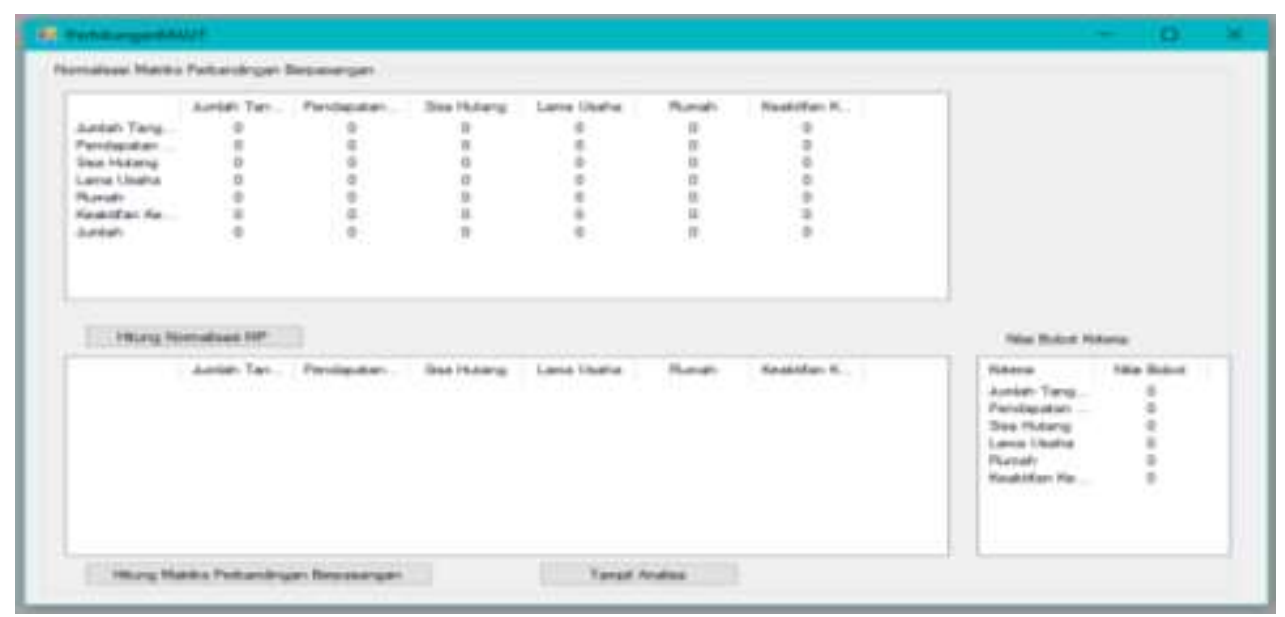

Gambar 6. Tampilan form MAUT

\subsection{Form Laporan}

Form laporan ialah form untuk menampilkan hasil data pegawai yang telah diproses. Berikut tampilan form laporan data pegawai:

\begin{tabular}{|c|c|c|c|}
\hline $10 / 09 / 2018$ & $\begin{array}{l}\frac{\text { kode }}{002} \\
004 \\
007 \\
001 \\
005 \\
008 \\
003 \\
009 \\
006 \\
010\end{array}$ & $\begin{array}{l}\text { nama } \\
\text { Budayati } \\
\text { Fuad Dahri } \\
\text { Vivi Juliana } \\
\text { Nurhayati } \\
\text { Riki Zunaid } \\
\text { Ahmad Yani } \\
\text { Suesti Efa } \\
\text { Rosdiana } \\
\text { Rubiyanti } \\
\text { Affrianto }\end{array}$ & $\begin{array}{l}\frac{\text { nilai rangking }}{65} \text { Ranking } 8 \\
77 \text { Ranking 5 } \\
84 \text { Ranking 2 } \\
63 \text { Ranking 10 } \\
65 \text { Ranking 9 } \\
80 \text { Ranking } 3 \\
90 \text { Ranking } 1 \\
79 \text { Ranking 4 } \\
73 \text { Ranking 6 } \\
65 \text { Ranking 7 }\end{array}$ \\
\hline
\end{tabular}

Gambar 7. Tampilan form laporan

\subsection{Pengujian}

Setelah implemetasi dilakukan maka langkah selanjutnya yaitu melakukan pengujian sistem terhadap proses perhitungan metode Multi Attribute Utility Theory. 


\subsection{Kelebihan dan Kelemahan Sistem}

Adapun kelebihan dan kelemahan Sistem Pendukung Keputusan untuk Menentukan Pemberian Pinjaman Modal Usaha dengan Metode Multi Attribute Utility Theory.

Adapun kelebihan dari sistem ini adalah sebagai berikut :

1. Sistem pendukung keputusan ini dapat melakukan perhitungan dalam menentukan Pemberian Pinjaman Modal Usaha dengan cepat, sehingga lebih menghemat waktu dan lebih efisien.

2. Sistem ini menggunakan metode Multi Attribute Utility Theory sebagai metode pemecahan masalah, sehingga hasil yang diperoleh sesuai dengan perhitungan manual.

3. Sistem dibuat dengan tampilan sederhana dan mudah digunakan oleh setiap user.

Adapun kelemahan sistem pendukung keputusan menentukan mutasi tugas kepolisian ini adalah :

1. Sistem pendukung keputusan ini hanya dapat digunakan untuk menentukan Pemberian Pinjaman Modal Usaha.

2. Parameter penilaian hanya 6 kriteria penilaian, jadi masih kurang optimal di bandingkan jika penilaian dengan parameter yang lebih banyak dalam tingkat akurasi hasil keputusan.

3. Sistem Pendukung Keputusan ini tidak bisa menambahkan data kriteria baru.

\section{KESIMPULAN}

Berdasarkan analisa pada permasalahan yang terjadi dalam kasus yang diangkat tentang Menentukan Pemberian Pinjaman Modal, maka dapat diambil kesimpulan sebagai berikut :

1. Sistem yang dibangun ini dapat membantu dalam menentukan calon penerima pinjaman modal usaha dengan menggunakan metode Multi Attribute Utillity Theory yang berbasis desktop.

2. Metode Multi Attribute Utillity Theory digunakan sebagai model dalam pengambilan keputusan yang merupakan metode fleksibel dalam menentukan prioritas dengan banyak kriteria dan dapat digunakan untuk menentukan pemberian pinjaman modal.

3. Dengan perancangan dan implementasi Sistem Pendukung Keputusan pemberian pinjaman modal usaha ini dengan metode Multi Attribute Utillity Theory, dapat dengan mudah melakukan pendataan calon kandidat yang akan diberikan pinjaman modal usaha dan serta menghasilkan output berupa laporan yang dapat dilakukan dengan cepat, tepat dan akurat.

\section{REFERENCES}

[1] Hamdani, Selywita Deviana, 2013. Sistem Pendukung Keputusan Pemilihan Supplier Obat Menggunakan Metode Fuzzy Tsukamoto. Jurnal Ilmiah SISFOTENIKA,3(1),22.

[2] Latjamudin,Al-Bahra Bin, 2012, Analisis Dan Design Sistem Informasi, Yogyakarta.

[3] Nofriansyah Dicky, Defit Sarjon, 2017.Multi Criteria Decision Making (MCDM) pada Sistem Pendukung Keputusan, Yogayakarta

[4] Rosa A. S \& M. Shalahuddin, 2013, Rekayasa Perangkat Lunak Terstruktur dan Berorientasi Objek, Bandung: Informatika Bandung.

[5] YA Elisabet, Sudewi, AW Cindi Amelia, 2016. Sistem Pendukung Keputusan Kelayakan Sertifikasi Guru dengan Menggunkan Metode SAW (Simple Additive Weighting) (Studi Kasusu : SMAN 1 Pringsewu). Jurnal TAM( Technology Acceptance Model), 7,1718.

[6] Aris, Supriyadi Wawan, Prayogo Dwiki, Wardiyanto Affan, Pratama Yudi Dian. Aplikasi Sistem Informasi Penggajian Pegawai Pada Kecamatan Mauk Kabupaten Tangerang. Jurnal STMIK AMIKOM Yogyakarta, 6(8), 1-2

[7] Kusrini. (2007). Konsep dan Aplikasi Sistem Pendukung Keputusan. Yogyakarta: Andi

[8] Ladjamuddin bin Al Bahra, 2005.Analisis dan Desain Sistem Informasi. Yogyakarta: Graha Ilmu

[9] Musliadi, K.H. 2013. Tips Cepat Bekerja dengan Database di Ms Office Access 2013. Yogyakarta: Andi

[10] Ningtyas Alfiyah Mulyo, Satyareni Diema Hernyka, Masrur. M. Perancangan Sistem Pendukung Keputusan untuk Menentukan Siswa Berprestasi Menggunkan Metode Ahp (Analytical Hierarchy Process) Berbasis Java. Jurnal Nusantara of Enginering 3(1) 23-24 